\title{
INCOME RISK IN PROPERTY VALUATION FOR LOAN SECURITY PURPOSES
}

\author{
Ewelina Nawrocka, M.Sc. \\ Department of Investment and Real Estate \\ University of Gdansk \\ e-mail: ewelina.nawrocka@ug.edu.pl
}

\begin{abstract}
Under the provisions of the standard Valuation to Secure Debt made by the Polish Federation of Valuers' Associations, in preparing the appraisal report for this purpose, the valuer, among other things, is "obligated to identify risk areas related to the property concerned, including the anticipated changes in the property market and the risk related to how the property is assessed by investors". The article discusses the assessment of the risk of incomes generated by a commercial property which is to constitute loan security. Factors influencing the variability of incomes taken into consideration in the income approach to property valuation are subject to detailed analysis. The article analyses the assessment of the risk of earning income different from that expected from the property constituting loan security with the use of statistical measures. The main purpose of the article is to propose the application of statistical measures for income risk assessment. Auxiliary goals are listing the factors which influence the variability of incomes in property valuation and characteristic features of modern office space in the Polish Tricity (i.e. Gdansk, Sopot, Gdynia) near the Baltic Sea, with the analysis of rents and vacancies. The article analyzes data from the Tricity property market over the period $2009-$ 2016.
\end{abstract}

Key words: risk, income, commercial property, valuation, loan.

JEL Classification: C49, E30, R33.

Citation: Nawrocka E., 2018, Income Risk in Property Valuation for Loan Security Purposes, Real Estate Management and Valuation, vol. 26, no. 2, pp. 12-22.

DOI: $10.2478 /$ remav-2018-0012

\section{Introduction}

Following the 2007-2008 global crisis related to property financing, the awareness of banks has increased (AEBI et al. 2012, p. 3213). Loan applications for financing property development projects, as well as projects where the already-existing property constitutes loan security, are thoroughly analyzed and assessed.

When making loan decisions secured by real property, the value of this property has to be determined. Real property is a capital-intensive commodity, and the volume of capital engaged in the property makes it an important element of the economy and a significant element in the investors' portfolios. It should be stressed that, as far as the number of concluded loan agreements is concerned, the residential mortgage market is the largest. However, as far as the value of loans granted is concerned, the commercial property market is predominant (SHAPIRO et al. 2013, p. 348). Commercial properties - the subject of study in this article - are identified with properties capable of generating periodical incomes from property use or ownership, taking the form of capital flows in time (LIPIŃSKI 2000, p. 30). These incomes can come from rent paid by tenants or the share of the landlord in the operational income generated by business activities carried out with the use of the property (TROJANOWSKI 2002, p. 31). 
The risk accompanying a given undertaking and future liquidity of the loan down-payment should be carefully scrutinized during the analysis of loan applications for such real properties. When commercial properties for rent are to constitute loan security, an assessment criterion seems to be the risk of generating incomes at the expected level from which the borrower will receive the payback. The article analyses incomes from modern office space in the Polish Tricity (i.e. Gdansk, Sopot, Gdynia) near the Baltic Sea. The impact of the factors decisive to the variability of incomes on their risk assessment in reference to the conditions and rules of estimating the real property value in the income approach will be the subject of study.

When valuing commercial property, the valuer should try to get full information about the property, as its estimated value amounts to millions and, therefore, the correctness of the results involves great responsibility. The professional standard for property valuers Valuation for Loan Security Purposes, issued in the form of the Minister of Infrastructure Communication of 4 January 2010, obligates, among other things, property valuers in Poland to attach risk assessment to the valuation survey of the property. According to the Standard, the Appendix should "(...) indicate risk areas related to the property under valuation, including expected changes on a given property market, and the risk connected with the valuation of a given property by investors, together with a general opinion on the trend of the impact of the above on the future value of the property." The article analyses the assessment of the risk of earning income different from that expected from a property being used as loan security with the use of statistical measures.

The main purpose of the article is to propose the application of statistical measures for the risk assessment of the amount of income. Auxiliary goals are listing the factors which influence the variability of income in property valuation and the characteristic features of modern office space in the Tricity, with the analysis of rents and vacancies.

The article analyses data from the Tricity property market over the period 2009 - 2016. It is based on the critical analysis of literature and binding laws. The results of simulations and analyses are presented in tables, backed with comments. Classic variation measures were used for statistical calculations: variance, standard deviation and the coefficient of variation.

\section{Income risk from a commercial property}

The available literature widely describes the concept of risk. The definition of risk refers, among others, to innovation processes (NAHOTKO 1996, p. 79), corporate financing (DAMODARAN 2007, p. 258), investment decisions (JAJUGA K, JAJUGA T. 2002, p. 98), and also to the human nature and human perception of risk or aversion to risk (KAHNEMAN, TVERSKY 1979, p. 264, AF WÅHLBERG 2011, p. 241). The concept of uncertainty is generally identified with the concept of risk. However, as early as in 1921, F.H. Knight pointed to the difference between these categories. In his book Risk, Uncertainty and Profit, this renowned economist separated a measurable part from the scope of uncertainty (as a result of calculations or on the basis of statistical data from the past) and called it risk, and the immeasurable uncertainty was treated as the remainder (KNIGHT 1964, p. 234). In the late 1970s, W. Behrens and P.M. Hawranek wrote the Manual for the Preparation of Industrial Feasibility Studies, which was not published in Poland until the 1990s, and, since then, has been one of the basic tools for preparing the financial models of investment projects. The authors of the Manual had a different concept of risk and uncertainty. They claimed: "The difference between risk and uncertainty is related to the decision maker's knowledge of the probable occurrence of certain events. Risk is present when the probabilities associated with various outcomes may be estimated on the basis of historical data. Uncertainty exists when the probabilities of outcome have to be assigned subjectively, since there are no historical data" (BEHRENS, HAWRANEK 1993, p. 334).

Risk discussed in the present article refers to a commercial property serving as loan security. The issue will be further analyzed in terms of - partially - real estate valuation risk. M. Cicharska and Ł. Reksa point out that accepting security in the form of a mortgage can be preceded by incorrect valuation. Such a scenario may be connected with a few factors, i.e. (CICHARSKA, REKSA 2008, p. 97):

- the lack of full and comprehensive information about the property and transaction prices;

- methodological error (including incorrect data selection or method of valuation);

- human error.

This article skips human and methodological errors of valuation. The valuation as such, however, will not be considered improper, but burdened with a risk resulting from the lack of full and 
comprehensive information on real estate on the local market, including the demand and supply of modern office space, market rents, operating fees, the number of vacancies or the expected activities within the premises.

\section{Conditions of income variability in real estate valuation}

Real estate investigated for purposes of this article may be valued in the income approach by the investment method, which is applicable for properties generating income in the form of rent. In order to determine the value of properties which will generate incomes at a stable level in the long run, a simple capitalization technique should be applied. "The technique of cash flow discounting should be applied in the case of properties whose real value of the future possible incomes may be subject to changes or whose incomes may be generated in the short run only" (ŹRÓBEK (ed.) 2006, p. 155). The value of real estate in this technique is stipulated according to the formula:

$$
V=\frac{N O I_{1}}{(1+r)^{1}}+\frac{N O I_{2}}{(1+r)^{2}}+\cdots+\frac{N O I_{n}}{(1+r)^{n}}+\frac{R V}{(1+r)^{n}}
$$

where:

NOI - net operating income,

$r \quad$ - discount rate,

$R V \quad$ - residual value of the property.

In general terms, the possibility of generating incomes from office space is determined by the efficient commercialization of the property's area and attempts to retain the recruited tenant at the given premises as well as meeting the tenant's needs. Tenants' preferences concerning the choice of office space depend on the sector (ADNAN et al. 2015, p. 276). The results of research carried out by M. Rymarzak and M. Madera for the Tricity office building market and CB Richard Ellis for the Warsaw market show that the main reasons for tenants abandoning the currently occupied office space are: poor technical condition of offices and buildings, poor infrastructure and excessively high rent. Significant factors to tenants selecting office space were public transport, the level of rent, the volume of operating fees, the budget for finishing works for the tenant and the arrangeability of the space (RYMARZAK, MADERA 2014, pp. 367-368; CB RICHARD ELLIS 2013). Among the factors mentioned by respondents, there are two which have a significant impact on the volume of incomes generated by the real property, i.e. the rent and operating fees. An additional third factor, indirectly resulting from the tenant's decision, is the vacancy rate, related to the attractiveness and availability of the office space on the local market. These data are used for estimating net operating income from the property. This processes involves a few steps, namely:

STEP 1. Potential gross income (PGI)

$$
\text { Potential Gross Income }=\text { leasable area } \cdot(\text { rent }+ \text { operating fees }) \cdot 12 \text { months }
$$

STEP 2. Efficient gross income (EGI)

$$
E G I=P G I \cdot(1-\text { vacancy rate })^{*}
$$

* Losses due to overdue rent payment and incentives for tenants, if they exist, are taken into consideration.

STEP 3. Operating expenses (OE)

$$
O E=\text { leasable area } \cdot \text { not re }- \text { invoicing costs } \cdot 12 \text { months }
$$

STEP 4. Net operating income (NOI)

$$
N O I=E G I-O E
$$

During property valuation, in order to define net operational income, market conditions are taken into consideration, including market rental fee, market level of operating costs and market level of vacancies. Individual pieces of information concerning the property under valuation are applicable only when the volume and possibility of receiving income out of the real property result from charging the valued real estate ius ad rem and ius in rem (CYMERMAN ET AL. 2011, p. 136). Generally speaking, when property leases signed for a definite period of time apply for the object under assessment, the level of rent resulting from the leases is assumed until their expiry.

Reasons which may result in incomes from office premises lower than those assumed include: 
- an increase in the number of vacancies caused by an increase in the supply of office space in the region;

- a market drop in rents resulting from the increase in the supply of office space and an attempt to retain tenants at the current location;

- tenants' insolvency;

- higher operating fees.

The provisions of the lease may grant a given tenant a separate way of settling operating fees and other settling. A typical lease is signed with a triple net rent (net-net-net lease), where the landlord finances refurbishment of the building, and the remaining types of operating costs are bestowed upon the tenant (RYMARZAK, MADERA 2014, p. 364), therefore, the variability of operating costs was not taken into consideration in the analysis.

Because the lease includes a provision concerning a deposit in the form of multiple amounts of monthly rent, the tenant's insolvency was also not taken into consideration in further analysis. Moreover, according to the interpretative note of the Polish Federation of Valuers' Associations in Warsaw concerning the income approach in property valuation, "the technique of income flow discounting is applied for stipulating the market value of real property for which, in a given period of time - called the forecasting period - a variable level of income flows is assumed, and the assumption of the variability of incomes results from the currently carried out or planned operations in the property or from the contracts charging the real property. This means that the variability in the level of income flows does not result from the forecasted future changes taking place on the market or in the property's environment" (PKZW, NI 2, point 4.3.1). Therefore, the factors mentioned above would bear impact on the value of property by reflecting them in the volume of cap rate $r$. The variability of incomes will result, however, from the provisions of lease concluded for a definite period of time and from the operations carried out or planned in the real property.

\section{Data and Methods}

\subsection{Situation on the Tricity modern office space market}

For the purpose of the article, research on the stability of incomes generated by modern office space in the Tricity was carried out. Following the previously-mentioned definition of risk saying that risk is a measurable part of uncertainty and that historical data - among other things - affect risk assessment, the article presents an in-depth analysis of the development of Tricity office space over the period 2009-2016.

The research published in 2016 confirms that information from the media and information portals influences risk valuation (TSAI ET AL. 2016, p. 111). Data on the office market come mainly from information available from articles and reports made for the local market.

According to reports on the situation on the real estate market, after the dynamic year 2008, the Tricity office market entered a period of stagnation. Rents dropped by an average of $10 \%$ to the rate of $€ 13-16 / \mathrm{m}^{2} /$ month and the tenants' market started to prevail. Developers completed started-up projects and cared about the retention of current tenants more than acquiring new ones. The supply of office space was many times higher than absorption and, in 2010, the volume of vacancies was more than $17 \%$. After the world crisis, banks tightened their requirements when granting loans in regards to the developers' own contribution and a higher ratio of concluding lease agreements prior to starting a project (prelease) (AGENCJA ROZWOJU POMORZA 2010). Starting in 2011, a dynamic revival has been observed on the lease market. The absorption of office space exceeded new supply and the vacancy rate dropped to the level of $10 \%$ in 2011, and to about $9 \%$ in the following year. Developers became more active, and since 2013 more than $60,000 \mathrm{~m}^{2}$ of modern office space has been finding its way to the regional market every year. The absorption of new space is more or less at the same level, with a vacancy rate at the level of $10-11 \%$ at the end of 2016.

In 2012, the Tricity transaction rent oscillated in the range of $€ 12-14 / \mathrm{m}^{2} /$ month, with the highest rental fees recorded in Gdynia at that time (JONES LANG LASALLE 2012). However, the strongest and dominating office center in the whole Tricity has been Gdańsk, in particular its Gdańsk-Oliwa and Przymorze-Uniwersytet districts, with two leading office complexes: Olivia Business Center (OBC) and Alchemia. In Gdynia, office buildings are clustered around Łużycka Street in the district of Mały Kack, neighboring Gdynia-Redłowo. Currently, base rents in the Tricity fall in the range of $€$ 11-13.5 $/ \mathrm{m}^{2} /$ month, while the average base rent for modern office space amounts to $€ 13.5 / \mathrm{m}^{2} / \mathrm{month}$ 
(RAPORT CBRE IVQ2016). In the 2016 summary, local real property market experts gave a positive opinion about changes in office space resources on the local market. Below are a couple of their opinions from the report Udany rok rynku biurowego w Trójmieście (Successful Year of the Office Market in the Tricity). M. Wiśniewski, CEO in the Tricity branch office of CBRE agency, observes that demand for new Class A space exceeds supply and, therefore, many leases are concluded for space under construction. M. Polkowski, Head of Research and Consulting at JLL, says that large spaces are the most difficult to find. By the end of 2016, available vacancies amounted to 70,000 $\mathrm{m}^{2}$ total, but few of them were large-sized. Currently, developers are constructing new offices of about 110,000 $\mathrm{m}^{2}$. This does not mean that the Tricity market is oversaturated with office space. M. Brożek from Torus Company (Alchemia Complex) says that a growing number of large companies are drawn to the Tricity by the quality of life, the availability of skilled staff, and developing business and businessrelated infrastructure. He also points out that high-class specialists find it easier to move to Gdańsk than to other cities in Poland. M. Wiśniewski adds that there is also the argument of clean air, as major conurbations in southern Poland have been battling with large-scale problem of smog (BUDNIK 2016).

Activities carried out or planned in the nearest future will be decisive to the stability of the real estate market. In 2017, two large-sized office buildings will be competed, i.e. Olivia Star (part of Olivia Business Center Complex) and Argon Building (within Alchemia Complex). Olivia Star will be the highest building in the Tricity, reaching $156 \mathrm{~m}$ and offering $43,700 \mathrm{~m}^{2}$ of office space for rent. The other building - Argon, belonging to Torus Company, will offer $39,000 \mathrm{~m}^{2}$ of office space. Both premises have partially booked out their space to renowned global companies. Another project in this region, with the working name of Olivia Seven, will add to the office space market some $30,000 \mathrm{~m}^{2}$ to the office space market, with its completion planned for 2018. It is highly possible that two office buildings owned by Skanska Property Poland, with the total planned space of $42,000 \mathrm{~m}^{2}$, will be completed in 2019; these will neighbor Alchemia complex (BRANCEWICZ 2016).

In his publication, Abdul Hamid Mar Iman says that the absorption of office space grows pro rata to an increase in employment. If the number of newly employed office workers increase by $10 \%$, the expected growth in the absorption of office space will also amount to $10 \%$. In the long run, however, the growth in absorption cannot be much higher than the increase in the number of jobs (HAMID 2007, p. 116). CBRE experts forecast that, in 2017, the vacancy rate should remain stable with a downward trend, simply due to the relatively high level of absorption, and developers' activity remaining at a comparative level (REGIONALNY RYNEK BIUROWY, 4 Q 2016).

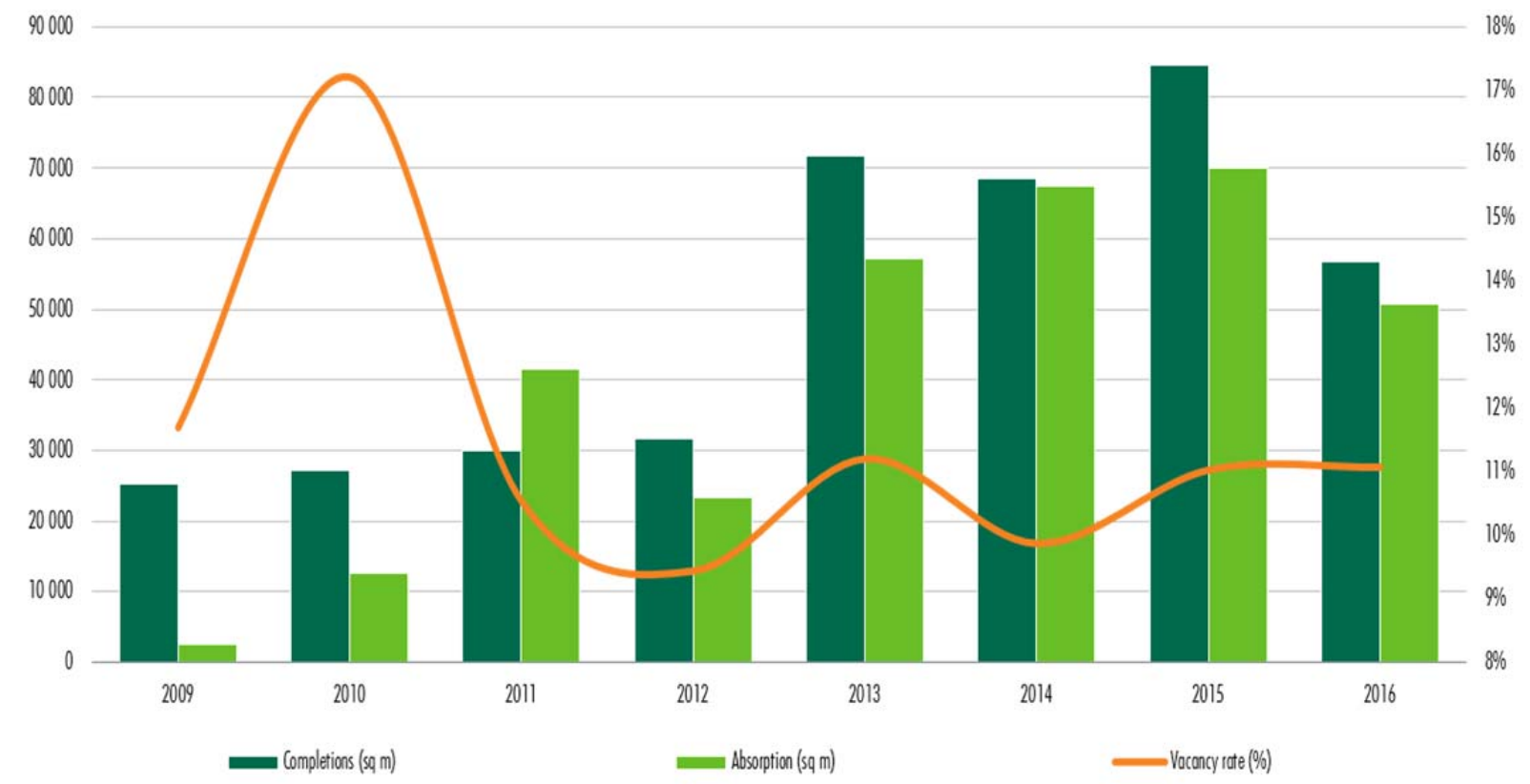

Fig. 1. New supply, absorption and vacancy rate in Tricity. Source: CBRE REPORT: "REGIONALNY RYNEK BIUROWY, 4 Q 2016" (REGIONAL OFFICE MARKET, 4 Q 2016 (written consent for publication from CBRE Research \& Consultancy Team obtained on 13.03.2017). 
The current level of absorption following 2012 has been, on average, $62,000 \mathrm{~m}^{2}$ annually, as illustrated by Fig.1. After 2012, the average level of absorption has been within the range of $10 \%-11 \%$. The above-mentioned data on new supply show that some $83,000 \mathrm{~m}^{2}$ of new office space will be brought onto the local market in 2017, while in subsequent years this will be about $30,000 \mathrm{~m}^{2}$ and $42,000 \mathrm{~m}^{2}$ respectively. Therefore, the average annual increase will amount to ca. $52,000 \mathrm{~m}^{2}$, which - at the retention of the current absorption at the level of $62,000 \mathrm{~m}^{2}$ - should be absorbed by local relocations from the office buildings which fail to meet tenants' expectations and by major foreign companies which enter the Polish market.

\subsection{Methods of assessing income variability risk}

Measures of the variability of the results of the observations were used for risk assessment in this article, including the expected value and standard deviation. Assuming that a given commercial real property has a finite number of variations of forecast net incomes, and we are familiar with the probability distribution of their occurrence under the anticipated economic conditions, the risk in real estate valuation may be quantified with the use of probabilistic methods. Net operating profit from the office property in the annual perspective is the variable.

The expected value as the average probability distribution of occurrence of a given level of incomes was determined according to the formula

$$
E\left(N O I_{t}\right)=\sum_{j=1}^{n} \rho_{t j} \cdot N O I_{t j}
$$

where:

$\mathrm{NOI}_{\mathrm{tj}} \quad-\mathrm{j}$-th level of net operating income in year $\mathrm{t}$,

$\rho_{\mathrm{tj}} \quad-$ the probability of occurrence of the $\mathrm{j}-\mathrm{th}$ level of net operating incomes in year $\mathrm{t}$,

$\mathrm{j}=1,2,3, \ldots, \mathrm{n}$ - the number of analysed levels of net incomes from the commercial real property,

$\mathrm{t}$

- following year in the period of forecasting incomes in property valuation.

Having taken into account the above-mentioned assumptions and symbols, the variance of net operating income $\sigma_{t}^{2}\left(\mathrm{NOI}_{t}\right)$ was defined for each year, in line with the following formula (ACZEL 2000, p. 124):

$$
\sigma_{t}^{2}\left(N O I_{t}\right)=\sum_{t=1}^{n}\left(N O I_{t j}-E\left(N O I_{t}\right)\right)^{2} \cdot \rho_{t j}
$$

The square root of the variance will constitute the standard deviation of the incomes $\sigma\left(\mathrm{NOI}_{\mathrm{t}}\right)$, which, in this case, signifies the scale of dispersion of the acquirable values of DON around the value of the expected net operating income from the property. The higher the deviation of the obtainable net operating income from the expected income, the higher the value of the standard deviation of income, and, therefore, the higher the income risk in real property valuation.

A relative measure of risk which allows for linking the risk with the expected income is the coefficient of variation $\mathrm{CV}$ :

$$
C V=\frac{\sigma\left(\mathrm{NOI}_{t}\right)}{E\left(\mathrm{NOI}_{t}\right)}
$$

The coefficient of variation allows for stipulating the strength of variation according to the following brackets:

0-0.2 weak variation;

0.2-0.4 moderate variation;

0.4-0.6 strong variation;

0.6 and more very strong variation.

The coefficient of variation is the simplest measure of relative risk. It is a dimensionless quantity. In this article, this coefficient will make it possible to stipulate the level of risk per expected value unit of income.

\section{Empirical results}

\subsection{Estimating net operating income}

The income from Gdańsk (in the Tricity) Class A office building of 20,000 $\mathrm{m}^{2}$ of leasable area will be analyzed.

Assumptions for the valuation variant: 
Ongoing modernization and renovation works: none

Planned modernization and renovation works: 2019 - replacing stairwell wall lining and major repairs of passenger lifts; cost PLN 240,000.

Market level of vacancies: $11.1 \%$.

Average base rent in Class A buildings: $€ 13.5 / \mathrm{m}^{2} /$ month.

Operating costs were determined at the level of $€ 4 / \mathrm{m}^{2} /$ month.

Triple net lease is used for the building as well as on the market.

Two leases were signed for large spaces occupied by key tenants.

Tenant A: area $8,000 \mathrm{~m}^{2}$, rent $€ 14 / \mathrm{m}^{2} /$ month, the lease is binding till the end of 2019 .

Tenant B: area $6,000 \mathrm{~m}^{2}$, rent $€ 13.5 / \mathrm{m}^{2} /$ month, the lease is binding till the end of 2020 .

Tenants for smaller premises: total area $6,000 \mathrm{~m}^{2}$, rent $€ 13 / \mathrm{m}^{2} / \mathrm{month}$, leases for $4,000 \mathrm{~m}^{2}$ were signed for a definite period of time and are binding till the end of 2018, the other leases were signed for a total area of $1,000 \mathrm{~m}^{2}$ for an indefinite period of time.

Unleased area is $1,000 \mathrm{~m}^{2}$, i.e. $5 \%$ of the leasable area of the building.

The research published in 2005 confirms that many cases of default occur within the first few years of taking out a loan (GROVENSTEIN et al. 2005, p. 367). Therefore, for the purpose of income risk assessment, a simulation for the five-year period of 2017-2021 was carried out. In this period, the terms of leases signed for a definite period of time will expire, and for the final year of the simulation market terms were applied.

The following three scenarios were assumed for the determination of income risk:

Scenario I - realistic

- base rent was determined at the current market level of $€ 13.5 / \mathrm{m}^{2} /$ month,

- the volume of vacancies was assumed at the highest level in the period under analysis, i.e. $17 \%$ in 2010 when the supply of office space was many times higher than absorption (see Fig.1).

According to the analysis, in the next a few years, the regional market will grow by more than 150,000 $\mathrm{m}^{2}$ of modern office space. In spite of the fact that experts assume absorption at the current level, Scenario I assumes a realistic assumption, i.e. an increase in the volume of unleased space.

Scenario II - average

- base rent was determined at $€ 12.25 / \mathrm{m}^{2} /$ month,

- the volume of vacancies was assumed at the current market level of $11.1 \%$.

By assuming the volume of vacancies at the current level and a simultaneous expected increase in the supply of new office space in the region, there will be a possible drop in the market base rent. Market analysis shows the average rent to fall within the brackets of $€ 11-13.5 / \mathrm{m}^{2} / \mathrm{month}$. The mean value of this range is $€ 12.25 / \mathrm{m}^{2} /$ month and, for this value, a drop in rents was planned in Scenario II.

Scenario III - pessimistic

- base rent was determined at the lowest level of $€ 11 / \mathrm{m}^{2} /$ month,

- the volume of vacancies was assumed at the highest level in the period under analysis, i.e. $17 \%$ in 2010 (see Fig.1).

By assuming the highest level of unleased space $(17 \%)$ in the period under analysis, along with a simultaneous drop in rents to the lowest level of $€ 11 / \mathrm{m}^{2} /$ month, a pessimistic course of events is analyzed in this scenario.

The probability distributions of the forecasted property income from the building $\rho_{t j}$ were assessed by experts as: Scenario I - 40\%, Scenario II - 30\%, Scenario III - 30\%.

Applying the rules of income determination in the income approach of property valuation, in the period when the leases are binding for the definite period of time, the terms specified in agreements were applied (in Table 1, they are marked in grey); for other space, current market terms were adopted.

The rents for individual tenants in the period 2017-2021 for Scenario I are presented in Table 1. For the other scenarios, the rents were adopted accordingly to Scenario I with the provision of the assumptions presented above, including market rent at the level of $€ 12.25 / \mathrm{m}^{2} /$ month for Scenario II and $€ 11 / \mathrm{m}^{2} /$ month for Scenario III.

Having taken into account all the assumptions mentioned above, net operating income for three scenarios was calculated for five subsequent years. Table 2 presents the results of the calculation. 
Rents for Scenario I for the period 2017-2021

Table 1

\begin{tabular}{lccrrrrr}
\hline \multicolumn{1}{c}{ Specification } & $\begin{array}{c}\text { Space } \\
\left(\mathrm{m}^{2}\right)\end{array}$ & $\begin{array}{c}\text { Rent from lease } \\
\left(€ / \mathrm{m}^{2} / \mathrm{month}\right)\end{array}$ & \multicolumn{4}{c}{$\begin{array}{c}\text { Rent for individual spaces in } \\
\text { subsequent years of simulation }\end{array}$} \\
\cline { 4 - 9 } & 20,000 & & 2017 & 2018 & 2019 & 2020 & 2021 \\
\hline Space available for a year & 8,000 & 14 & 14 & 14 & 14 & 13.5 & 13.5 \\
\hline Space of Tenant A & 6,000 & 13.5 & 13.5 & 13.5 & 13.5 & 13.5 & 13.5 \\
\hline Space of Tenant B & 4,000 & 13 & 13 & 13.5 & 13.5 & 13.5 \\
\hline Space C & 1,000 & & 13.5 & 13.5 & 13.5 & 13.5 & 13.5 \\
\hline Space D & 1,000 & & 13.5 & 13.5 & 13.5 \\
\hline Unleased space E & & & & 13.5 & & & \\
\hline
\end{tabular}

Source: own study.

Table 2

Simulation of real property income for three scenarios in the period 2017-2021

\begin{tabular}{|c|c|c|c|c|c|c|}
\hline \multirow{2}{*}{$j \backslash t$} & \multirow{2}{*}{$\begin{array}{l}\text { Base rent and } \\
\text { vacancy rate }\end{array}$} & \multicolumn{5}{|c|}{ Net operating income ${ }_{t j}(€)$} \\
\hline & & 2017 & 2018 & 2019 & 2020 & 2021 \\
\hline Scenario I & $€ 13.5 / 17 \%$ & $3,054,000$ & $3,054,000$ & $2,838,000$ & $3,030,000$ & $39,115,714$ \\
\hline Scenario II & $€ 12.25 / 11.1 \%$ & $3,039,000$ & $3,039,000$ & $2,763,000$ & $2,835,000$ & $38,560,714$ \\
\hline Scenario III & $€ 11 / 17 \%$ & $3,024,000$ & $3,024,000$ & $2,688,000$ & $2,640,000$ & $31,431,429$ \\
\hline
\end{tabular}

Source: own study.

Income from the final period of the simulation was increased by the residual value $(R V)$ of the property, which was determined on the basis of the established rental rate and unleased area percentage share (see Table 3) according to the formula:

$$
R V=\frac{N O I_{n}}{r}
$$

Residual value is understood here as the income from the investment exit.

The capitalization rate was assumed at $7 \%$ and determined on the basis of real transactions on the Tricity Class A modern office space market.

Table 3

Determination of residual value of the real property in 2021 for three simulation scenarios

\begin{tabular}{lrrr}
\hline Specification & Scenario I & Scenario II & Scenario III \\
\hline PGI & $4,200,000$ & $3,900,000$ & $3,600,000$ \\
\hline EGI & $3,486,000$ & $3,467,100$ & $2,988,000$ \\
\hline OE & 960,000 & 960,000 & 960,000 \\
\hline NOI & $2,526,000$ & $2,507,100$ & $2,028,000$ \\
\hline \multicolumn{4}{|}{} \\
\hline RV & $36,085,714$ & $35,815,714$ & $28,971,429$ \\
\hline & Source: own study.
\end{tabular}

\subsection{Application of measures of dispersion in office building income risk assessment}

Using the output data presented above, in line with point 3.3 of the article, office building income risk will be determined for valuation for loan security purposes. Calculated first was the expected value of income for five subsequent years for three income scenarios and probability distribution. Following 
this, variance, standard deviation and the coefficient of variation were calculated. Table 4 shows the results.

Table 4

Determination of measures of variation on the basis of income from office building in 2017-2021

\begin{tabular}{|c|c|c|c|c|c|c|}
\hline \multirow{2}{*}{$j \backslash t$} & \multirow{2}{*}{$\mathrm{p}_{\mathrm{tj}}$} & \multicolumn{5}{|c|}{ Net operating income ${ }_{t j}(€)$} \\
\hline & & 2017 & 2018 & 2019 & 2020 & $2021^{*}$ \\
\hline Scenario I & 0.40 & $3,054,000$ & $3,054,000$ & $2,838,000$ & $3,030,000$ & $39,115,714$ \\
\hline Scenario II & 0.30 & $3,039,000$ & $3,039,000$ & $2,763,000$ & $2,835,000$ & $38,560,714$ \\
\hline Scenario III & 0.30 & $3,024,000$ & $3,024,000$ & $2,688,000$ & $2,640,000$ & $31,431,429$ \\
\hline
\end{tabular}

\begin{tabular}{lrrrrr}
\hline $\begin{array}{l}\text { Expected value of } \\
\text { cash flow E(NOIt) }\end{array}$ & $3,040,500$ & $3,040,500$ & $2,770,500$ & $2,854,500$ & $36,643,929$ \\
\hline $\begin{array}{l}\text { Variance } \sigma^{2} \mathrm{t} \\
\text { (NOI) }\end{array}$ & $155,250,000$ & $155,250,000$ & $3,881,250,000$ & $26,237,250,000$ & $11,697,156,964,286$ \\
\hline $\begin{array}{l}\text { Standard } \\
\text { deviation } \\
\begin{array}{l}\sigma \mathrm{t}(\mathrm{NOI}) \\
\text { Coefficient of }\end{array}\end{array}$ & 12,460 & 12,460 & 62,300 & 161,979 & $3,420,111$ \\
variation CV & 0.0041 & 0.0041 & 0.0225 & 0.0567 & 0.0933 \\
\hline${ }^{*}$ i & & & &
\end{tabular}

${ }^{*}$ in $2021 \mathrm{NOI}+\mathrm{RV}$

Source: own study.

In the first two years, standard deviation of $€ 12,000$ against the income expected value of over $€ 3,000,000$ is a result which can be omitted entirely in risk assessment, and risk can be assumed as almost non-existent. The coefficient of variation is 0.0041 , i.e. less than 0.01 of risk falls for a unit of income expected value in 2017 and 2018, when most of the incomes from the real property are generated by leases signed for a definite period of time and the income is stable. The lease for $4,000 \mathrm{~m}^{2}$ with a rent of $€ 13 / \mathrm{m}^{2} /$ month will expire by the end of 2018, and starting in 2019 a new market rent was assumed at - depending on the scenario - $€ 13.5 / \mathrm{m}^{2} /$ month, $€ 12.25 / \mathrm{m}^{2} / \mathrm{month}$ and $€ 11$ $/ \mathrm{m}^{2} /$ month respectively. Moreover, necessary renovation works were planned in 2019: the replacement of stairwell wall lining and major repairs to passenger lifts; the total cost of renovation is anticipated to amount to PLN 240,000. After taking the above factors into account, the expected income value dropped from ca. $€ 3,000,000$ to ca. $€ 2,770,000$, and standard deviation increased from ca. $€ 12,500$ to $€ 62,300$. The coefficient of variation was 0.02 , which means that income diversification is still poor and risk is determined as low. The lease for the space of $8,000 \mathrm{~m}^{2}$ with a key tenant will expire by the end of 2019, and, in 2020, for another $6,000 \mathrm{~m}^{2}$ with the second major tenant. Taking into account the change from contract rent to market rent, income risk increases. In 2019, the expected value of $€ 2,770,000$ does not grow much, amounting to $€ 2,850,000$, while the standard deviation nearly triples, amounting to ca. $€ 162,000$. The final year of the forecast contains the residual value which reflects the future value of the real property on the basis of market terms for the three scenarios. If the residual value was not taken into account, the expected value of income would drop to $€ 2,770,000$, while standard deviation would increase to $€ 237,000$. The coefficient of variation would be 0.085 . However, taking into account the residual value, income risk increases to a level of 0.09 in the final year of forecast. Nevertheless, this result shows that the diversification of income is still poor. The 0.09 of risk falls per unit of expected value of income, which means that risk is relatively low.

\section{Discussion and conclusions}

While assessing real property income risk, it is crucial to determine at what level and for how long the commercial real property will have a stable situation guaranteed by leases signed for a definite period of time. When a major part of the available leasable space generates a stable income, the risk of the value of income being other than expected is low. The situation will be different if most of the area is 
leased on market terms. On the basis of the analysis of historical data on the Tricity modern office space market concerning rents, absorption and the percentage share of unleased space, the article presents three scenarios of market terms: realistic, average and pessimistic. For risk assessment in the three scenarios, historically assessed lowest rents and the highest volume of vacancies were taken into account. The analysis showed that, even with such assumptions for the final year of the forecast, the space leased on market terms was still distinguished by a low level of income risk.

The study of income carried out with measures of dispersion may be a suggestion for risk assessment for property valuers who valuate commercial properties for loan security purposes and have the ability to undertake such statistical analysis. Such risk assessment attached as an appendix to the valuation survey seems to expand knowledge of the market and be a significant help to banks in making loan decisions. The proposed statistical analysis could also be applied as a separate tool, independently of the valuers report.

\section{References}

ACZEL, 2000, Statystyka w zarzadzaniu (Statistics in Management), Wydawnictwo Naukowe PWN, Warszawa.

ADNAN Y.M., DAUD M.D., MoHAmEd RAZALI M.N., 2015, A Multi-criteria Framework for Office Tenants' Preferences at Office Buildings, International Journal of Strategic Property Management, Vol. 19(3).

Aebi V., SABAto G., Schmid M., 2012, Risk Management, Corporate Governance, and Bank Performance in the Financial Crisis, Journal of Banking \& Finance, Vol. 36.

Agencja Rozwoju PomorZa, 2010, Powierzchnie biurowe Trójmiasto - Raport 2010 (Office Space Tricity 2010 Report), PDF file from www.gdansk.pl (accessed on 07.11.2010).

BEHRENS W., HAWRANEK P.M., 1993, Poradnik przygotowania przemystowych studiów feasibility. Wydanie II poprawione i rozszerzone, (Manual for the Preparation of Industrial Feasibility Studies. Newly Revised and Expanded Edition.) UNIDO.

BRANCEWICZ M., 2017, Zagłębie biurowców rozrasta się (The Region of Office Buildings Is Expanding), Serwis Wiadomości, web portal trójmiasto.pl (access on 11 March 2017).

BUDNIK E., 2017, Udany rok rynku biurowego w Trójmieście (A Successful Year of Office Market in Tricity), Serwis Dom, web portal trójmiasto.pl (accessed on 10 March 2017).

CB RICHARD ELLIS, 2013, What`s Next? Badanie preferencji najemców biurowych 2013 (The Survey of Office Tenants' Preferences 2013),

http:/ / www.cbre.eu/portal/pls/portal/res_rep.show_report?report_id=2778 (access on 9 March 2017).

CBRE RESEARCH, 2016, Regionalny rynek biurowy, 4 kw. 2016 (Regional Office Market, 4Q2016) Global Research Gateway, PDF file from http://www.cbre.pl/pl_pl/research (access on 10 March 2017).

CICHARSKA M., REKSA Ł., 2008, Ryzyko w finansowaniu hipotecznym (Risk in Mortgage Financing, (in:) Nieruchomość, kredyt, hipoteka (Real Property, Loan, Mortgage), joint publication ed. by G. GŁóWKI, Poltext, Warszawa.

CYMERMAn R., CYMERMAn J., JeSIOTR M., JeSIOTR G., 2011, Szacowanie nieruchomości (Property Valuation), Wydanie III, Wydawnictwo Uczelniane Politechniki Koszalińskiej, Koszalin.

Grovenstein R.A., Harding J.P., SiRmans C.F., ThebPanYA S., TuRnbull G.K., 2005, Commercial Mortgage Underwriting: How Well do Lenders Manage the Risks?, Journal of Housing Economics, Vol. 14.

GwizDAŁa J., 2011, Ryzyko kredytowe w działalności banku komercyjnego (Credit Risk in Commercial Bank Operations), Wydawnictwo Uniwersytetu Gdańskiego, Gdańsk.

Hamid Mar Iman A., 2007, Property Supply and Demand, Penerbit, Universiti Teknologi Malaysia, Skudai.

JONES LANG LASALLE, 2012, Trójmiejski rynek nieruchomości, wrzesień 2012 (The Tricity Real Estate Market September 2012), PDF file from http://www.jll.pl/poland/pl-pl/raporty (access on 05.02.2013).

KAHNEMAn D., TVERSKy A., 1979, Prospect Theory: An Analysis of Decision under Risk, Econometrica, Vol. 47, No. 2, www.jstor.org/stable/1914185 (access on 03.03.2017).

KNiGHT F.H., 1964, Risk, Uncertainty and Profit, Prints of Economic Classics, Bookseller, New York.

KOMUNIKAT MINISTRA INFRASTRUKTURY z dnia 4 stycznia 2010 r., Standard zawodowy rzeczoznawców majątkowych pt. Wycena dla zabezpieczenia wierzytelności, (COMMUNICATION OF MINISTER OF INFRASTRUCTURE of4 January 2010, Professional Standard for Property Valuers: Valuation for Loan 
Security Purposes), Dziennik Urzędowy Ministra Infrastruktury nr 1 (Official Journal of Minister of Infrastrucure), Warszawa, 8 January 2010.

LIPIŃSKI J., 2000, Deweloper na rynku nieruchomości (Developer on the Real Estate Market), Nieruchomości C.H. Beck, no 2.

NAHOTKO S., 1996, Efektywność i ryzyko w procesach innowacyjnych (modele i przykłady) (Effectiveness and Rsk in Innovation Processes (Models and Examples), TNOiK, Bydgoszcz.

RYMARZAK M., MADERA M., 2014, Rozwój budownictwa zrównoważonego na przykładzie powierzchni biurowej w Trójmieście (The Development of Sustainable Construction Illustrated by an Example of Office Space in Tricity) , Zarządzanie i Finanse, Journal of Management and Finance, Vol. 12, No. 4.

SHAPIRO E., MACKMIN D., SAMS G., 2013, Modern Methods of Valuation. Eleventh Edition, Routledge, New York.

TrojANOWSKI D., 2002, Nieruchomość komercyjna i jej miejsce (Commercial Property and its Place), Nieruchomość C.H. Beck, no 4.

Tsai F-T., Lu H-M., Hung M-W., 2016, The Impact of News Articles and Corporate Disclosure on Credit Risk Valuation, Journal of Banking \& Finance, Vol. 68.

AF WÅHLBERG A. E., 2001, The theoretical features of some current approaches to risk perception, Journal of Risk Research, vol. 4.

ŹRÓBEK S. (ed.), 2006, Metodyka określania wartości rynkowej nieruchomości (Methodology of Determination of Market Value of Real Property), Educaterra, Olsztyn. 